\title{
SYNTHESIS AND ANTIOXIDANT EVALUATION OF SOME NEW ALLOBETULIN ESTERS
}

\author{
S. Arrous ${ }^{1, *}$, I. Boudebouz ${ }^{1}$, O. Voronova ${ }^{2}$, E. Plotnikov ${ }^{2}$ and A. Bakibaev ${ }^{1}$ \\ ${ }^{1}$ Department of Chemistry, Tomsk State University, Tomsk - 634050, (Tomsk) Russia \\ ${ }^{2}$ Department of Chemistry, Tomsk Polytechnic University, Tomsk - 634050, (Tomsk) Russia \\ *E-mail: parroussalinkov@yahoo.com
}

ABSTRACT

A series of 3-O-haloacyl allobetulin were synthesized via acylation of allobetulin by haloacetic (trifluro,difluorochloro, trichloro, monochloro) acid in $\mathrm{CHCl}_{3}$ at $70{ }^{\circ} \mathrm{C}$. The structure of allobetulin was modified at C-3 position, and esters 3a-d were obtained in high yields. Moreover the reactions do not need a catalyst. The structures of all synthesized compounds were confirmed by various spectroscopic methods (IR and NMR) and tested for antioxidant activity.

Keywords: triterpene, betulin, allobetulin, esterification, haloacetic acid, antioxidant.

○ RASĀYAN. All rights reserved

\section{INTRODUCTION}

Triterpenes are compounds derived from the natural precursor, squalene. After the cyclization of epoxidized squalene (oxidosqualene) numerous polycyclic triterpenic structures are formed, mostly with the C-3 hydroxyl group, one or more carboxyl and additional hydroxyl groups may present as well. The presence of hydroxyl functional group in such a polycyclic structure makes the possibility to conduct various chemical transformations leading to numerous new derivatives.

Recently, various interesting biological activities were found for this class of compounds, which in combination with their low toxicities prompt an increased research effort ${ }^{1,2}$. More remarkably, the oleanane group that exhibits a number of relevant pharmacological activities.

Allobetulin (19ק,28-epoxyoleanan-3-ol) 1, the oleanane series terpenoid, is widely represented in the plant world. In particular, it is a part of the extractive substances of birch bark, the main component of which is betulin, the lupane series triterpenoid. Synthetic allobetulin has been easily obtained from betulin by acid-catalyzed intramolecular cyclization, which involves the hydroxymethyl group $\mathrm{CH}_{2} \mathrm{OH}$ of C-28 and $\mathrm{C}_{29}=\mathrm{C}_{20}$ double bond, accompanied by Wagner-Meerwein type rearrangement. ${ }^{3}$

Allobetulin, is the excellent example of chemical reactivity of C-3 hydroxyl group and the esterification of this latter leading to the receiving of diverse derivatives with significant pharmacological properties.

The syntheses of different ester derivatives of allobetulin have been described comprehensively in the literature via acylation of the $3-\beta \mathrm{OH}$ function. ${ }^{4-6}$

Allobetulin and its derivatives bearing an ester group at C-3 show a wide range of biological activity. They have an anti-inflammatory activity comparable to ortophen (diclofenac) ${ }^{6,7}$, antiulcer activity ${ }^{7,8}$, antiviral activity ${ }^{9}$, antifeedant and insecticidal activities. ${ }^{10}$

An analysis of published data suggests that allobetulin derivatives containing acyl groups are a promising source of new biologically active substances. We report herein the synthesis of a series of some new halogen-containing esters of allobetulin, and evaluation of their antioxidant activities.

\section{EXPERIMENTAL}

${ }^{1} \mathrm{H}$ and ${ }^{13} \mathrm{C}$ NMR spectra have been recorded via Bruker AVANCE 400 III HD spectrometer (Bruker, Billerica, MA, USA), 400.17 and $100.63 \mathrm{MHz}$, respectively. Chemical shifts (d) are reported relative to tetramethylsilane peak set at $0.00 \mathrm{ppm}$. In the case of multiplets, the signals are reported as intervals. Rasayan J. Chem., 12(3), 1032-1037(2019) 
Signals were abbreviated as s, singlet; d, doublet; t, triplet; $m$, multiplet. Coupling constants were expressed in $\mathrm{Hz}$.

TLC was conducted on Sorbfil plates using $\mathrm{C}_{6} \mathrm{H}_{6}: \mathrm{CH}_{2} \mathrm{Cl}_{2}: \mathrm{CH}_{3} \mathrm{OH}$ (5:5:1). Spots were detected by spraying TLC plates with $1 \%$ phosphomolybdic acid and heating at $110{ }^{\circ} \mathrm{C}$ for 5 minutes to show a characteristic blue color.

Infrared spectra were obtained directly from the products using Bruker Tensor 27 FT-IR Spectrometer. The spectra were recorded in the range of 400 to $4000 \mathrm{~cm}^{-1}$. Melting temperatures have been detected in open capillaries using Buchi apparatus.

\section{Voltammetric Approach for Antioxidant Activity Assessment}

In this work, we applied the voltammetric technic for the measurement of antioxidant properties. This method was previously used for antioxidant activity determination of pharmaceutical substrate and biological objects ${ }^{11,12}$.

The voltammetric analyzer TA-2 (Tomanalyt, Tomsk, Russia) was used to record cathode current. We used a glass cup with a background electrolyte solution of $10 \mathrm{~cm} 3$ in volume as an electrochemical cell. A three-electrode circuit with an indicator mercury film electrode, a silver-silver chloride reference electrode and silver-silver chloride auxiliary electrode was used with $0.1 \mathrm{M} \mathrm{NaClO} 4$ in ethanol $(96 \%$ ethyl alcohol) as a background solution.

The change of current ER $\mathrm{O}_{2}$ was recalculated to the activity of the test substance. The coefficient of antioxidant activity was expressed in $\mu \mathrm{mol}^{1} \mathrm{l}^{-1} \mathrm{~min}^{-1}$, which reflects the amount of active oxygen radicals interacted with the antioxidants in a time period, as follows:

$$
K=\frac{C^{0}}{t}\left(1-\frac{I}{I 0}\right)
$$

Where $\mathrm{C}^{0}\left[\mu \mathrm{mol} \cdot \mathrm{l}^{-1}\right]$ is the oxygen concentration in solution, $\mathrm{I}$ is the ER $\mathrm{O}_{2}$ current with the investigated substance addition in the solution, $\mathrm{I}_{\mathrm{o}}$ is the limiting ER $\mathrm{O}_{2}$ current without the substance in the solution, $\mathrm{t}$ (min) is the time of the interaction between the reactive oxygen species and an antioxidant at the working electrode.

Samples were examined at a final concentration of $0.0125 \%(0.125 \mathrm{mg} / \mathrm{ml})$. The sample of a mass 0.0100 $\mathrm{g}$ was taken and dissolved in $1 \mathrm{ml}$ of DMF and then $3 \mathrm{ml}$ of $96 \%$ ethanol was added. The aliquot of $0.5 \mathrm{ml}$ was taken from the resulting solution and placed into the electrochemical cell. Three parallel tests were made, the average coefficient of antioxidant activity was calculated. The results were statistically processed.

\section{General Procedure}

To a solution of betulin (1.0 equivalent) in $\mathrm{CHCl}_{3} 20 \mathrm{ml}$ was added haloacetic acid (2.5 equivalents) and stirred at $70{ }^{\circ} \mathrm{C}$ for $2-6$ hours. After completion of the reaction (as indicated by TLC), the filtrate was evaporated and the methanol was added to form a precipitate, which was separated by filtration. The white residue was recrystallized from acetone.

\section{Allobetulin 3-O- monochloroacetate (3a)}

yield $96 \%, \mathrm{Rf}=0.56, \mathrm{mp}=248{ }^{\circ} \mathrm{C}$. IR spectrum $(\mathrm{KBr}, v, \mathrm{~cm}-1): 2926.7-2866.2\left(-\mathrm{CH}_{3}\right.$ and $\left.-\mathrm{CH}_{2}\right), 1749.4$ $(\mathrm{C}=\mathrm{O}), 1292.0$ and $1031.1(\mathrm{C}-\mathrm{O}-\mathrm{C}), 799.5(\mathrm{C}-\mathrm{Cl}) .{ }^{1} \mathrm{H}$ NMR spectrum $\left(400.17 \mathrm{MHz}, \mathrm{CDCl}_{3}, \delta, \mathrm{ppm}\right.$, $J / \mathrm{Hz}): 0.70(3 \mathrm{H}, \mathrm{s}), 0.74(3 \mathrm{H}, \mathrm{s}), 0.80(3 \mathrm{H}, \mathrm{s}), 0.81(3 \mathrm{H}, \mathrm{s}), 0.85(3 \mathrm{H}, \mathrm{s}), 0.86(3 \mathrm{H}, \mathrm{s}), 0.91(3 \mathrm{H}, \mathrm{s})$, $4.03\left(2 \mathrm{H}, \mathrm{s}, \mathrm{CH}_{2} \mathrm{CO}\right), 3.38(1 \mathrm{H}, \mathrm{d}, J=7.6,28-\mathrm{Ha}), 3.50(1 \mathrm{H}, \mathrm{s}, 19 \mathrm{a}-\mathrm{H}), 3.71(1 \mathrm{H}, \mathrm{d}, J=7.6,28-\mathrm{Hb})$, $4.50(1 \mathrm{H}, \mathrm{m}, 3 \mathrm{a}-\mathrm{H}) .{ }^{13} \mathrm{C}$ NMR spectrum $\left(100.63 \mathrm{MHz}, \mathrm{CDCl}_{3}, \delta, \mathrm{ppm}\right): 12.47$ (C27), 14.66 (C24), 15.42 (C26), 15.52 (C25), 17.06 (C6), 19.99 (C11), 22.52 (Cl- $\left.\underline{\mathbf{C H}}_{2} \mathrm{COO}\right), 23.51$ (C29 or C30), $25.17\left(\mathrm{CH}_{2}\right)$, $25.36\left(\mathrm{CH}_{2}\right), 26.88\left(\mathrm{CH}_{2}\right), 27.75(\mathrm{C} 23), 31.65(\mathrm{C} 29$ or $\mathrm{C} 30), 32.77(\mathrm{C} 21), 33.06(\mathrm{C} 7), 35.20(\mathrm{C} 13), 35.65$ (C17), 36.12 (C16), 37.00 (C10), 37.48 (C4), 39.59 (C1),39.69 (C), 40.44 (C), 45.75 (C18), 49.94 (C9), 54.48 (C5), 70.15 (C28), 82.36 (C3), 87.03 (C19), 166.19 ( $\left.\mathrm{ClCH}_{2} \underline{\mathbf{C O O}}\right)$. 
RASĀYAN J. Chem.

Vol. 12 | No. 3 |1032 - 1037| July - September | 2019

Allobetulin 3-O- difluorochloroacetate (3b)

yield $98 \%, \mathrm{Rf}=0.57, \mathrm{mp}=258{ }^{\circ} \mathrm{C}$. IR spectrum $(\mathrm{KBr}, \mathrm{v}, \mathrm{cm}-1): 2943.6-2881.2\left(-\mathrm{CH}_{3}\right.$ and $\left.-\mathrm{CH}_{2}\right), 1765.4$ $(\mathrm{C}=\mathrm{O}), 1169.7$ and 1033.4 (C-O-C), 732.6 and $834.6(\mathrm{C}-\mathrm{Cl}), 1136.2(\mathrm{C}-\mathrm{F}) .{ }^{1} \mathrm{H}$ NMR spectrum $(400.17$ $\left.\mathrm{MHz}, \mathrm{CDCl}_{3}, \delta, \mathrm{ppm}, J / \mathrm{Hz}\right): 0.81(3 \mathrm{H}, \mathrm{s}), 0.91(3 \mathrm{H}, \mathrm{s}), 0.92(3 \mathrm{H}, \mathrm{s}), 0.93(3 \mathrm{H}, \mathrm{s}), 0.94(3 \mathrm{H}, \mathrm{s}), 0.96$ (3 $\mathrm{H}, \mathrm{s}), 1.01(3 \mathrm{H}, \mathrm{s}), 3.48(1 \mathrm{H}, \mathrm{d}, J=7.6,28-\mathrm{Ha}), 3.56(1 \mathrm{H}, \mathrm{s}, 19 \mathrm{a}-\mathrm{H}), 3.79(1 \mathrm{H}, \mathrm{d}, J=7.6,28-\mathrm{Hb}), 4.69$ $(1 \mathrm{H}, \mathrm{m}, 3 \mathrm{a}-\mathrm{H}) .{ }^{13} \mathrm{C}$ NMR spectrum $\left(100.63 \mathrm{MHz}, \mathrm{CDCl}_{3}, \delta, \mathrm{ppm}\right): 13.50(\mathrm{C} 27), 15.70(\mathrm{C} 24), 16.26$ (C26), 16.53 (C25), 18.05 (C6), 21.04 (C11), 24.55 (C29 or C30), $26.23\left(\mathrm{CH}_{2}\right), 26.37\left(\mathrm{CH}_{2}\right), 26.42\left(\mathrm{CH}_{2}\right)$, 27.40 (C2), 27.81 (C23), 28.80 (C29 or C30), 32.69 (C21), 33.77 (C7), 34.11 (C13), 36.27 (C17), 36.71 (C16), 37.16 (C10), 38.24 (C4), 38.42 (C1), 40.63 (C), 40.74 (C), 41.48 (C), 46.80 (C18), 50.97 (C9), 55.47 (C5), 72.35 (C28), 86.43 (C3), 88.00 (C19), 117.05 (들 $\left.{ }_{2} \mathrm{COO}\right), 159.13$ (CClF $\left.\underline{\mathbf{C O O}}^{\mathbf{C}}\right)$.

\begin{abstract}
Allobetulin 3-O- trifluoroacetate (3c)
yield $99 \%, \mathrm{Rf}=0.54, \mathrm{mp}=268{ }^{\circ} \mathrm{C}$. IR spectrum $(\mathrm{KBr}, \mathrm{v}, \mathrm{cm}-1): 2944.6-2869.0\left(-\mathrm{CH}_{3}\right.$ and $\left.-\mathrm{CH}_{2}\right), 1770.1$ $(\mathrm{C}=\mathrm{O}), 1219.3,1188.6$ and $1033.0(\mathrm{C}-\mathrm{O}-\mathrm{C}) .1166 .6(\mathrm{C}-\mathrm{F}) .{ }^{1} \mathrm{H}$ NMR spectrum $\left(400.17 \mathrm{MHz}, \mathrm{CDCl}_{3}, \delta\right.$, ppm, J/Hz): $0.72(3 \mathrm{H}, \mathrm{s}), 0.81(3 \mathrm{H}, \mathrm{s}), 0.82(3 \mathrm{H}, \mathrm{s}), 0.84(3 \mathrm{H}, \mathrm{s}), 0.85(3 \mathrm{H}, \mathrm{s}), 0.87(3 \mathrm{H}, \mathrm{s}), 0.91(3 \mathrm{H}$, s), $3.37(1 \mathrm{H}, \mathrm{d}, J=7.6,28-\mathrm{Ha}), 3.47(1 \mathrm{H}, \mathrm{s}, 19 \mathrm{a}-\mathrm{H}), 3.70(1 \mathrm{H}, \mathrm{d}, J=7.6,28-\mathrm{Hb}), 4.63(1 \mathrm{H}, \mathrm{m}, 3 \mathrm{a}-\mathrm{H})$. ${ }^{13} \mathrm{C}$ NMR spectrum (100.63 MHz, $\left.\mathrm{CDCl}_{3}, \delta, \mathrm{ppm}\right): 12.46$ (C27), 14.73 (C24), 15.22 (C26), 15.49 (C25), 17.04 (C6), $20.01(\mathrm{C} 11), 22.23\left(\mathrm{CH}_{2}\right), 23.52(\mathrm{C} 29$ or $\mathrm{C} 30), 25.49\left(\mathrm{CH}_{2}\right), 26.73\left(\mathrm{CH}_{2}\right), 26.84(\mathrm{C} 2), 27.77$ (C23), 31.66 (C29 or C30), 32.74 (C21), 33.09 (C7), 35.24 (C13), 35.69 (C17), 36.12 (C16), 37.05 (C10), 37.39 (C4), 39.60 (C1), 39.71 (C), 40.44 (C), 45.77 (C18), 49.94 (C9), 54.40 (C5), 70.22 (C28), 85.25 (C3), 86.93 (C19). 115.09 ( $\left.\underline{\mathbf{C F}}_{3} \mathrm{COO}\right), 156.57\left(\mathrm{CF}_{3} \underline{\mathbf{C O O}}\right)$.
\end{abstract}

\title{
Allobetulin 3-O- trichloroacetate (3d)
}

yield $96 \%, \mathrm{Rf}=0.55, \mathrm{mp}=285{ }^{\circ} \mathrm{C}$. IR spectrum $(\mathrm{KBr}, \mathrm{v}, \mathrm{cm}-1): 2946.1-2856.5\left(-\mathrm{CH}_{3}\right.$ and $\left.-\mathrm{CH}_{2}\right), 1763.5$ $(\mathrm{C}=\mathrm{O}), 1282.9$ and $1033.7(\mathrm{C}-\mathrm{O}-\mathrm{C}), 799.5(\mathrm{C}-\mathrm{Cl}) .{ }^{1} \mathrm{H}$ NMR spectrum $\left(400.17 \mathrm{MHz}, \mathrm{CDCl}_{3}, \delta, \mathrm{ppm}\right.$, $J / \mathrm{Hz}): 0.81(3 \mathrm{H}, \mathrm{s}), 0.91(3 \mathrm{H}, \mathrm{s}), 0.93(3 \mathrm{H}, \mathrm{s}), 0.94(3 \mathrm{H}, \mathrm{s}), 0.95(3 \mathrm{H}, \mathrm{s}), 0.99(3 \mathrm{H}, \mathrm{s}), 1.05(3 \mathrm{H}, \mathrm{s})$, $3.46(1 \mathrm{H}, \mathrm{d}, J=7.6,28-\mathrm{Ha}), 3.57(1 \mathrm{H}, \mathrm{s}, 19 \mathrm{a}-\mathrm{H}), 3.79(1 \mathrm{H}, \mathrm{d}, J=7.6,28-\mathrm{Hb}), 4.63(1 \mathrm{H}, \mathrm{m}, 3 \mathrm{a}-\mathrm{H}) .{ }^{13} \mathrm{C}$ NMR spectrum (100.63 MHz, $\left.\mathrm{CDCl}_{3}, \delta, \mathrm{ppm}\right): 14.25$ (C27), 15.70 (C24), 16.33 (C26), 16.53 (C25), 18.04 (C6), 21.05 (C11), $24.56(\mathrm{C} 29$ or $\mathrm{C} 30), 26.22\left(\mathrm{CH}_{2}\right), 26.41\left(\mathrm{CH}_{2}\right), 26.44\left(\mathrm{CH}_{2}\right), 26.52(\mathrm{C} 2), 27.90(\mathrm{C} 23)$, 28.80 (C29 or C30), 32.69 (C21), 33.78 (C7), 34.11 (C13), 36.25 (C17), 36.70 (C16), 37.11 (C10), 37.80 (C4), 38.44 (C1), 40.64 (C), 40.74 (C), 41.48 (C), 46.79 (C18), 50.95 (C9), 55.43 (C5), 71.23 (C28), 87.36 (C3), 88.03 (C19), 90.53 ( CCl $\left._{3} \mathrm{COO}\right), 161.68$ ( $\left.\mathrm{CCl}_{3} \underline{\mathbf{C O O}}\right)$.

\section{RESULTS AND DISCUSSION}

Allobetulin was synthesized directly from Betulin, according to the method described in the literature. ${ }^{13}$ The chemical structure of allobetulin was confirmed using ${ }^{1} \mathrm{H}$ and ${ }^{13} \mathrm{C}$ NMR and IR spectroscopy and then compared with the spectral data described in the literature. ${ }^{14}$

Previously, the allobetulin trifluoroacetate has been synthesized from betulin 3-acetate and trifluoroacetic anhydride ${ }^{9}$. However, in the present study, all our esters including allobetulin trifluoroacetate were synthesized from allobetulin directly by treating them with different haloacetic acids.

The synthesis of allobetulin esters is summarized in scheme-1. The structure of allobetulin $\mathbf{1}$ was modified at the C-3 position. Haloacetic acid 2a-d were introduced at the C-3 position in dry chloroform $\left(\mathrm{CHCl}_{3}\right)$ at reflux to obtain compounds 3a-d in high yields (96-99\%) after 2-6 $\mathrm{h}$.

The different reaction times of compounds 3a-d may be interpreted in terms of various factors. One of these factors is the acidity of haloacetic acid molecules. When a hydrogen atoms at the alpha position of acetic acid are replaced by halogens the acidity of the acetic acid molecule will increase with the addition of each subsequent halogen atom. Furthermore, the acidity of the mono-, di-, and trihalogenated series 2ad was enhanced with the increasing electronegativity of the halogen atom in the order $\mathrm{F}>\mathrm{Cl}>\mathrm{Br}>\mathrm{I}$. According to the reported acidities of acetic acid derivatives $\mathrm{ClF}_{2} \mathrm{CCOOH}$ pka=0.46 ${ }^{15}, \mathrm{CF}_{3} \mathrm{COOH}$ $\mathrm{pka}=0.23, \mathrm{ClCH}_{2} \mathrm{COOH} \mathrm{pka}=2.87, \mathrm{CCl}_{3} \mathrm{COOH} \mathrm{pka}=0.77^{16}$. Their acidity increases in the order $\mathbf{2 c}>\mathbf{2 b}$ $>\mathbf{2 d}>\mathbf{2 a}$. Thus, an increase in the acidity will increase the electrophilicity of the acid, the higher the 
electrophilicity of the acid the faster the reaction time of esterification. The time of reactions increases in the order $\mathbf{3 c}(2 \mathrm{~h})>\mathbf{3 b}(2.5 \mathrm{~h})>\mathbf{3 d}(5 \mathrm{~h})>\mathbf{3 a}(6 \mathrm{~h})$.

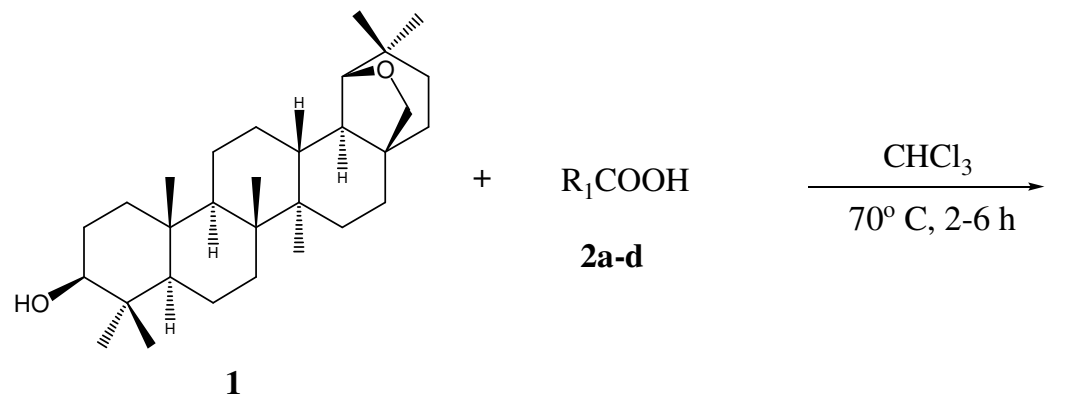

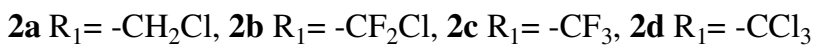
3a $\mathrm{R}_{2}=-\mathrm{CH}_{2} \mathrm{Cl}, \mathbf{3 b} \mathrm{R}_{2}=-\mathrm{CF}_{2} \mathrm{Cl}, \mathbf{3} \mathbf{c} \mathrm{R}_{2}=-\mathrm{CF}_{3}, \mathbf{3 d ~ \mathrm { R } _ { 2 }}=-\mathrm{CCl}_{3}$

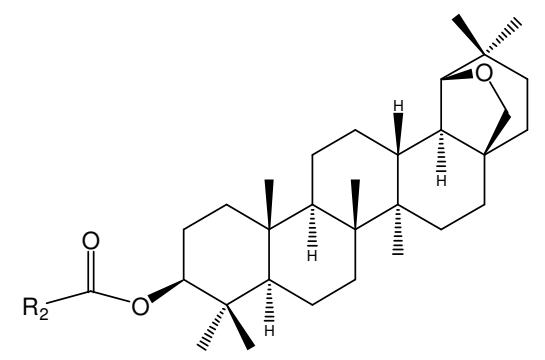

3a-d

Scheme-1: Synthesis of Allobetulin esters 3a-d

The composition and structure of adducts 3a-d were confirmed by IR, ${ }^{1} \mathrm{H}$ NMR and ${ }^{13} \mathrm{C}$ NMR spectra. In their IR spectra, the allobetulin esters have been characterized by the disappearance of $\mathrm{OH}$ band of allobetulin and appearance of new bands in the prepared compounds 3a-d such as the $\mathrm{C}=\mathrm{O}$-group at $1730-1775 \mathrm{~cm}^{-1}$ and of the $\mathrm{C}-\mathrm{O}$ ester group at $1000-1275 \mathrm{~cm}^{-1}$.

The bands of the carbon-chlorine bond are observed for chlorine-containing compounds $\mathbf{3 a} \mathbf{a} \mathbf{b}$ and $\mathbf{d}$ in low-frequency spectral regions: $670-850 \mathrm{~cm}^{-1}$. The IR spectra of fluorine-containing esters $\mathbf{3 b}$ and $\mathbf{3 c}$ contain intense bands associated with $\mathrm{C}-\mathrm{F}$ vibrations at 1166.6 and $1136.2 \mathrm{~cm}^{-1}$, respectively.

The ${ }^{1} \mathrm{H}$ NMR spectrum of allobetulin esters synthesized 3a-d contain characteristic signals of tetrahydrofuran ring, which appears as doublets of protons of $\mathrm{CH}_{2}$ group $(A B$ system), $\delta 3.45-3.78 \mathrm{ppm}$, and a singlet of $\mathrm{CH}$ group at 3.53-3.57 ppm. Comparison of the ${ }^{1} \mathrm{H}$ NMR spectra of 3a-d and allobetulin revealed an appreciable downfield shift of the C-3 proton signals as a result of introduction of an acyl group (the very characteristic resonance signal from an unsubstituted derivatives is usually at around 3.2$3.3 \mathrm{ppm}$, while substitution of carbon C-3 shifts this signal downfield by at least $1.0 \mathrm{ppm}$ ).

The IR spectrum of the derivative 3a showed the presence of a new strong pick at $1728 \mathrm{~cm}^{-1}$, characteristic to $\mathrm{C}=\mathrm{O}$ of ester, and the disappearance of alcohol absorption band between $3200-3600 \mathrm{~cm}^{-1}$ was indicative of esterification. In the ${ }^{1} \mathrm{H}$ NMR spectrum the $\mathrm{H}-3$ was shifted downfield from $3.22 \mathrm{ppm}$ in $\mathbf{1}$ to $4.50 \mathrm{ppm}$ in $\mathbf{3 a}$, and the same effect was observed in ${ }^{13} \mathrm{C}$ NMR as well from $78.99 \mathrm{ppm}$ in $\mathbf{1}$ to 82.36 $\mathrm{ppm}$ in 3a which indicates the acylation of allobetulin $\mathbf{1}$ at $\mathrm{C}-3$. The presence of chloroacetyl side chain $\mathrm{ClCH}_{2}$ was affirmed by the apparition of the characteristic signal at $4.07 \mathrm{ppm}$ as a singlet in ${ }^{1} \mathrm{H} \mathrm{NMR}$ and signal at $22.52 \mathrm{ppm}$ in ${ }^{13} \mathrm{C}$ NMR as well. Moreover, the resonance corresponding to the carbonyl ester was shown at $166.19 \mathrm{ppm}$ in the ${ }^{13} \mathrm{C} \mathrm{NMR}$.

The IR spectrum of the derivative $\mathbf{3 b}$ showed a new strong pick at $1732 \mathrm{~cm}^{-1}$ attributed to $\mathrm{C}=\mathrm{O}$ indicating acylation of compound $\mathbf{1}$ at C-3. Displacement of $\mathrm{H}-3$ signal from $3.22 \mathrm{ppm}$ in $\mathbf{1}$ to $4.69 \mathrm{ppm}$ in $\mathbf{3 b}$ in ${ }^{1} \mathrm{H}$ NMR and the downfield shift observed at C-3 signal from 78.99 ppm in $\mathbf{1}$ to 86.43 ppm in $\mathbf{3 b}$ in ${ }^{13} \mathrm{C}$ NMR confirm the presence of an ester-bearing C-3. Side chain was assured by characteristics signals at 117.05 ppm belonging to $\mathrm{C}_{-} \mathrm{ClF}_{2}$ group in the ${ }^{13} \mathrm{C}$ NMR spectrum, besides the new signal at $159.13 \mathrm{ppm}$ assignable to the carbonyl ester.

The presence of carboester groups in the molecule 3c was confirmed by the IR spectrum which displays the presence of new strong pick at $1736 \mathrm{~cm}^{-1}$ attributed to $\mathrm{C}=\mathrm{O}$ of an ester. The formation of the ester $\mathbf{3 c}$ was also proven by ${ }^{1} \mathrm{H}-\mathrm{NMR}$ which indicates downfield displacement of the multiplicity of $\mathrm{H}-3$ from 3.22 ppm in 1 to $4.63 \mathrm{ppm}$ in 3c. As it was shown in ${ }^{13} \mathrm{C}$ NMR by shift downfield of C-3 signal from 78.99 $\mathrm{ppm}$ in 1 to $85.25 \mathrm{ppm}$ in 3c. In addition, the presence of a signal at $115.09 \mathrm{ppm}$, which is associated with $\mathrm{CF}_{3}$ group and the signal belonging to the carbonyl ester that was observed at $\delta 156.57 \mathrm{ppm}$ have confirmed the achievement of esterification. The appearance of the new pick at $1732 \mathrm{~cm}^{-1}$ in the IR spectrum of $\mathbf{3 d}$ confirmed the presence of a carbonyl group in this compound. The 3-O-acylated ester 
exhibited multiplicity in ${ }^{1} \mathrm{H}$ NMR with the chemical shift being shifted significantly downfield from 3.22 $\mathrm{ppm}$ in $\mathbf{1}$ to $4.63 \mathrm{ppm}$ in $\mathbf{3 d}$. As it can be observed in its ${ }^{13} \mathrm{C} \mathrm{NMR}$, which displayed a displacement from $78.99 \mathrm{ppm}$ in 1 to $87.36 \mathrm{ppm} \mathbf{3 d}$. The change in the chemical shifts at C-3 affirmed the acylation of the hydroxy group. Furthermore, the presence of a signal at $90.53 \mathrm{ppm}$ corresponding to $\mathrm{CCl}_{3}$ group, and the signal at $161.68 \mathrm{ppm}$ assigned to the carbonyl group $(\mathrm{C}=\mathrm{O})$ in the ${ }^{13} \mathrm{C}$ NMR spectrum have confirmed the esterification at C-3.

\section{Pharmacology \\ Antioxidant Activity}

According to the results obtained by voltammetric technic (Fig.-1), all synthesized derivatives 3a-d exhibited good antioxidant activity in comparison with allobetulin 1. It should be noted that the activity of these Compounds 3a-d surpasses the activity of such well-known antioxidant like ascorbic acid 1.165 .

The improvement of the antioxidant activity of these compounds may be interpreted by the influence of the alkyl ester side chain. On the comparison between the compounds 3a-d, it was noticed that the presence of halogen at the alpha position of acetyl group results in an increase in the antioxidant activity. The presence of trihaloacetyl groups significantly enhanced the antioxidant activity of compounds $\mathbf{3 b}$-d in comparison with compound 3a with monohaloacetyl group.

Thus, The insertion of an alkyl side chain by using ester as linker has enhanced the antioxidant activity of allobetulin.

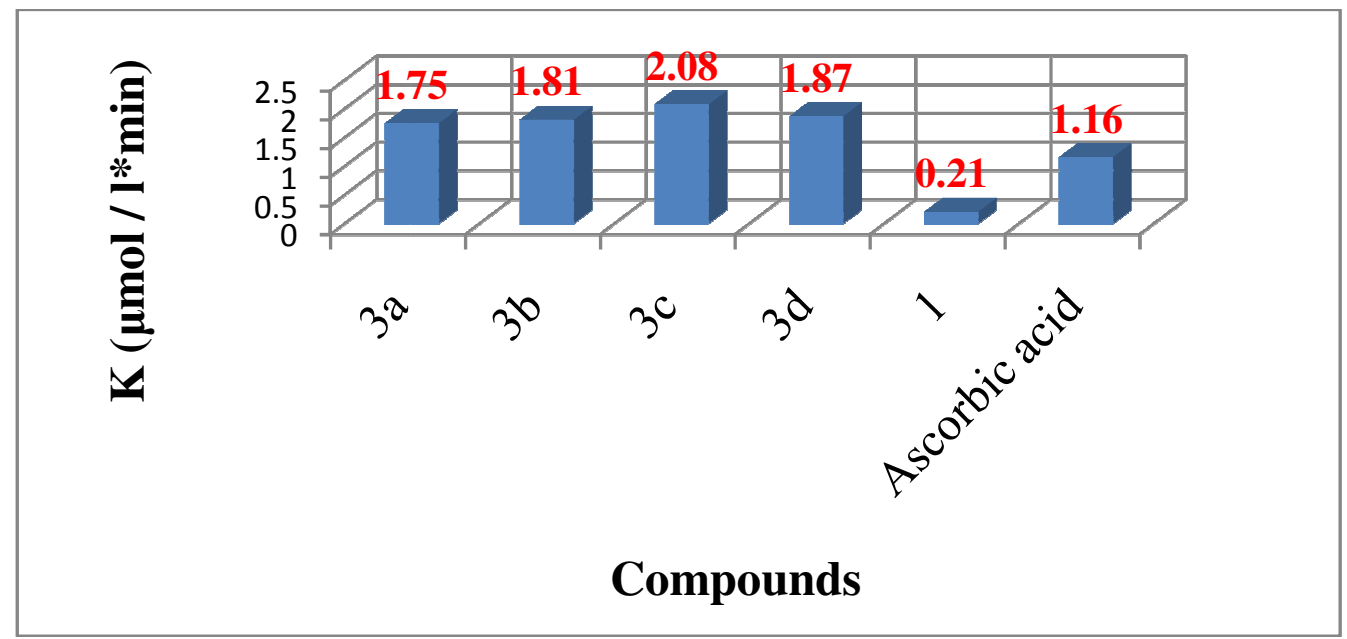

Fig.-1: Antioxidant Activity of Compounds 3a-d

\section{CONCLUSION}

In summary, A series of new ester derivatives of allobetulin has been described by applying a simple esterification reaction without need of a catalyst. All the compounds were obtained with excellent yield. As well as they showed good antioxidant activity in comparison with ascorbic acid.

\section{ACKNOWLEDGMENT}

This research was supported and financed by the Ministry of Education and Science of the Russian Federation (Grant No. 05-13108).

\section{REFERENCES}

1. G. A. Tolstikov, O. B. Flekhter, E. E. Shul'ts, L. A. Baltina and A. G. Tolstikov, Khim. Interes. Ust. Razv, 13, 1(2005).

2. P. Dzubak, M. Hajduch, D. Vydra, A. Hustova, M. Kvasnica, D. Biedermann, L. Markova and J. Sarek, Nat. Prod. Rep., 23, 394(2006), DOI: 10.1039/b515312n.

3. W. Dehaen, A. A. Mashentseva and T. S. Seitembetov, Molecules, 16, 2443(2011), DOI: 10.3390/molecules16032443. 
4. H. Schulze and K. Pieroh, Chem. Ber, 55, 2322(1922), DOI: 10.1002/cber19220550814.

5. O. B. Flekhter, N. I. Medvedeva, L. T. Karachurina, L. A. Baltina, F. S. Zarudi, F. Z. Galin, N. N. Kabalnova and G. A. Tolstikov, Pharm. Chem. J, 36, 488(2002), DOI: 10.1023/A:1021896722692.

6. P. A. Krasutsky, R. M. Carlson, WO 2002026761, PCT Int. Appl, 136, 294955 (2002).

7. O. B. Flekhter, N.I. Medvedeva, L. T. Karachurina, L. A. Baltina, F. Z. Galin, F. S. Zarudii and G. A. Tolstikov, Pharm. Chem. J, 39, 401(2005), DOI: 10.1007/s11094-005-0167-z.

8. O. B. Flekhter, L. R. Nigmatullina, L. A. Baltina, L. T. Karachurina, F. Z. Galin, F. S. Zarudii, G. A. Tolstikov, E. I. Boreko, N. I. Pavlova, S. N. Nikolaeva, O. V. Savinova, Pharm. Chem. J, 36, 484 (2002), DOI: 10.1023/A: 1021844705853.

9. R. M. Carlson, US Patent, 6369101, (2002).

10. M. P. Sokolyanskaya, N. I. Medvedeva, O. B. Flekhter, G. V. Benkovskaya, A. G. Nikolenko and F. Z. Galin, Agrokhimiya, 12, 48(2005).

11. E. Plotnikov, E. Korotkova, O. Voronova, E. Dorozhko, N. Bohan and S. Plotnikov, Physiology and pharmacology, 19, 107(2015).

12. S. K. Kabieva, O. A. Nurkenov, T. M. Seilkhanov, A. A. Bakibaev, A. M. Gazalieva, A. T. Takibaeva, O. A. Voronova, E. V. Plotnikov, Russian Journal of General Chemistry, 86, 1765(2016), DOI: $10.1134 / \mathrm{S} 1070363216080387$.

13. A. Vystrcil and J. Klinot, Collect. Czech. Chem. Commun, 24, 3279(1959), DOI: $10.1135 / \operatorname{ccc} 19593279$.

14. J. A. R. Salvador, R. M. A. Pinto, R. C. Santos, C. L. Roux, A. M. Beja and J. A. Paixão, Org. Biomol. Chem, 7, 508(2009), DOI: 10.1039/b814448f.

15. J. L. Kurz and J. M. Farrar, J. Am. Chem. Soc, 91, 6057(1969), DOI: 10.1021/ja01050a021.

16. V. H. Agreda and J. R. Zoeller, Acetic acid and its derivatives, CRC Press, new york, p. 286 (1992).

[RJC-5159/2019] 